\title{
Preliminary Study on TNFa-Blocker Activity of Amygdalus lycioides Spach Extracts
}

\author{
Raffaella Gaggeri ${ }^{1}$, Daniela Rossi*, ${ }^{1}$, Narges Hajikarimian ${ }^{1}$, Emanuela Martino $^{2}$, Francesco Bracco ${ }^{2}$, \\ Pietro Grisoli ${ }^{3}$, Cesare Dacarro ${ }^{3}$, Flavio Leoni ${ }^{4}$, Gabriele Mascheroni ${ }^{4}$, Simona Collina ${ }^{1}$ and \\ Ornella Azzolina ${ }^{1}$
}

\begin{abstract}
${ }^{1}$ Department of Pharmaceutical Chemistry, University of Pavia, Viale Taramelli, 12-27100 Pavia, Italy; ${ }^{2}$ Department of Territorial Ecology, University of Pavia, Via S. Epifanio, 14-27100 Pavia, Italy; ${ }^{3}$ Department of Experimental and Applied Pharmacology, University of Pavia, Viale Taramelli, 14-27100 Pavia, Italy; ${ }^{4}$ Italfarmaco Research Center, Viale dei Lavoratori, 54-20092 Cinisello Balsamo (MI), Italy
\end{abstract}

\begin{abstract}
Badam Talkh kuhi is an endemic species of Iran commonly used by native people as anti-inflammatory and antimicrobial remedy. The present study was aimed at investigating the folk claims of this plant, identified by us as Amygdalus lycioides Spach. Several extracts were prepared using various extraction procedures combined with solvents of different polarity. A decoction was firstly prepared according to the procedure of the folk medicine. Maceration (ME), Ultrasound-Assisted Extraction (USAE) and Microwave-Assisted Solvent Extraction (MASE) were then experimented using pure methanol $(\mathrm{MeOH})$ and $n$-hexane-acetone $(n-\mathrm{Hex}-\mathrm{Ac}, 50 \% \mathrm{v} / \mathrm{v})$. Concerning biological investigation, the antimicrobial potential of all extracts was firstly evaluated by employing the growth inhibition test. Then, the free radical scavenging effect of each extract was measured, given that reactive oxygen species (ROS) are involved in TNF $\alpha$-induced signaling pathways associated with inflammation. Finally, the anti-TNF $\alpha$ activity of the most active extracts was evaluated using in vitro and in vivo assays. Regarding the anti-inflammatory activity, decoction and MASE $n$-Hex/Ac extract inhibited the production of $\mathrm{TNF} \alpha$ with $\mathrm{IC}_{50}$ in the range of $120-390 \mu \mathrm{g} / \mathrm{ml}$ and $6-20 \mu \mathrm{g} / \mathrm{ml}$, respectively. Interestingly, after oral administration in mice, MASE $n$-Hex/Ac extract was effective in reducing TNF $\alpha$ of about $60 \%$. Moreover, treated animals did not show any signs of toxicity. Results herein reported clearly evidenced that Amygdalus lycioides Spach could be a valuable source of TNF $\alpha$-blockers effective against chronic inflammatory diseases.
\end{abstract}

Keywords: Amygdalus lycioides Spach, extraction procedures, anti-inflammatory properties, antimicrobial activity, free radical scavenging properties.

\section{INTRODUCTION}

Inflammation is an essential protective process preserving the integrity of organisms against physical, chemical and infective insults. However, repeated injuries of various aetiologies may induce chronic inflammation leading to prolonged damage of normal tissues. Chronic inflammation is thought to play a central role in the development of various diseases, including some cancers, atherosclerosis and chronic obstructive pulmonary disease [1]. Despite of the wide choice of drugs conventionally used in the treatment of chronic inflammation, there is an established need of new and safe anti-inflammatory agents, due to the discouraging toxicity profile of currently used drugs [2]. The discovery of endogenous molecules involved in the inflammatory process provides new targets for controlling inflammation. Following the discovery of the cytokine IL- $1 \beta[3,4]$ several different cytokines, termed pro-inflammatory cytokines [5], have been described to have a pivotal role in inflammation; among them one of the most important in sustaining inflammation is tumor necrosis factor alpha (TNF $\alpha)$ [6]. TNF $\alpha$ blockers represent a major advance in the treatment of

*Address correspondence to this author at the Department of Pharmaceutical Chemistry, University of Pavia, Viale Taramelli, 12-27100 Pavia, Italy; Tel: +390382987376; Fax: +390382422975; E-mail: daniela.rossi@unipv.it chronic inflammatory diseases, such as rheumatoid arthritis, bowel diseases and psoriasis [7].

Recently, the drug discovery process has been frequently focused on the screening of plant extracts commonly used in traditional medicines as source of novel therapeutic agents. In this context, the object of the present study was to evaluate the folk claims of Badam Talkh kuhi, an endemic Iranian species commonly used by native people as folk remedy in the treatment of various diseases since ancient time. In detail, its stem and branchelets decoction have been used for managing pain and inflammatory conditions, inflammatory skin disorders and infectious diseases [8].

To achieve our goal, different extracts were prepared, applying various extraction procedures combined with solvents of different polarity, and their biological properties were investigated.

\section{MATERIALS AND METHODS}

\subsection{Chemicals}

All solvents were purchased from Carlo Erba (Milan, Italy) and were of analytical grade.

2,2-Diphenyl-1-picrylhydrazyl radical and ascorbic acid were purchased from Sigma Chemicals (St Louis, MO, 
USA). Ampicillin and amphotericin B were purchased from Sigma-Aldrich S.r.l. (Milan, Italy) and kept at $4{ }^{\circ} \mathrm{C}$ in dessicator.

\subsection{Plant Material}

Stems and branchelets of Amygdalus lycioides Spach were collected in September 2007 at an altitude of $2400 \mathrm{~m}$ in an area near Teheran. A voucher specimen was deposited in the Herbarium of the University of Pavia (PAV 2007 11/15/01), Department of Territorial Ecology, University of Pavia, Via S. Epifanio, 14 - 27100 Pavia, Italy. Freshly cut plants were sorted out, dried in a drying room with active ventilation at room temperature (about 20-22 ${ }^{\circ} \mathrm{C}$ ) until they reached constant weight. The material was stored in dark conditions, into air tight polyethylene container. Branches were cut in small size, just before performing the extractions.

\subsection{Extraction Procedures}

\section{Decoction}

Dried stems and branchelets $(5 \mathrm{~g})$ were boiled in tap water $(100 \mathrm{ml})$ for 1 hour under mechanical stirring. The procedure was repeated three times. After each extraction, solvents were filtered, combined and dried under reduced pressure (Laborota 4000, Heidolph Instruments, Schwabach, Germany, temperature $40-45^{\circ} \mathrm{C}$ ).

\section{Maceration Extraction (ME)}

ME was performed at room temperature and in dark condition. Plant material (2 g) was macerated in the opportune solvent $(40 \mathrm{ml})$, under mechanical stirring for $36 \mathrm{~h}$.

\section{Ultrasound-Assisted Extraction (USAE)}

USAE was conducted in an ultrasonic bath $\left(\right.$ ELMA $^{\circledR}$ Transsonic T420 Morfelden-Walldorf, Germany), at room temperature, for $2 \mathrm{~h}$. The appropriate extraction solvent (40 $\mathrm{ml})$ was added to plant material $(2 \mathrm{~g})$.

\section{Microwave-Assisted Solvent Extraction (MASE)}

MASE was performed on a multimode Microwave apparatus using a closed-vessel system (MARSX press, CEM Corporation Matthews, NC, USA). The appropriate solvent $(20 \mathrm{ml})$ was added to plant material $(1 \mathrm{~g})$ and the samples heated at $120^{\circ} \mathrm{C}$ for $20 \mathrm{~min}$ with a power of $800 \mathrm{~W}$. Samples were cooled at room temperature before opening the vessels.

ME, USAE and MASE extraction procedures were performed either with or without drug pre-treatment with petroleum ether $10 \%(\mathrm{w} / \mathrm{v})$ for $30 \mathrm{~min}$ at room temperature under mechanical stirring [9]. Each extract was separated by filtration and solvent was evaporated to dryness under vacuum to $35^{\circ} \mathrm{C}$.

All dried samples obtained were kept at room temperature in dessicator.

\subsection{Antimicrobial Activity}

To evaluate antimicrobial properties of prepared extracts the following reference strains were used: Clostridium sporogenes ATCC 3584, Enterococcus hirae ATCC 10541, Staphylococcus aureus ATCC 6538, Streptococcus mutans ATCC 25175, Streptococcus pyogenes ATCC 19615, Escherichia coli ATCC 10536, Pseudomonas aeruginosa
ATCC 10145, Candida albicans ATCC 10231 and Aspergillus niger ATCC 16404.

\section{Growth Inhibition Test}

Antimicrobial activity was evaluated employing the agar disc diffusion method [10]. Stock sample solutions were prepared dissolving dried samples in DMSO in order to obtain a final concentration of $100 \mathrm{mg} / \mathrm{ml}$ of extracts. Stock standard solution of ampicillin and amphotericin B (concentration of $20 \mu \mathrm{g} / \mathrm{ml}$ in DMSO) was used as a positive control for bacteria and fungi, respectively. In both cases DMSO was used as a negative control.

The prepared suspension of bacterial and fungal strains was spread on Petri plates dispensed with Tryptone Soy Agar (TRS, Oxoid, Basingstoke, U.K.) for bacteria and Sabouraud Dextrose Agar (SAB, Oxoid, Basingstoke, U.K.) for fungi. The bacterial plates were then kept at $4^{\circ} \mathrm{C}$ for $2 \mathrm{~h}$ and afterwards were incubated for $24 \mathrm{~h}$ at $37^{\circ} \mathrm{C}$. The fungal plates were incubated at $25^{\circ} \mathrm{C}$ for $48 \mathrm{~h}$. Filter paper discs $(12$ $\mathrm{mm}$ in diameter) were impregnated with either $100 \mu \mathrm{l}$ of stock sample solution or $100 \mu$ l of stock standard solution and placed onto the agar plates, previously inoculated with the tested microorganisms. Results were expressed as mean \pm SE of inhibitory diameter zone (IZD) of three independent experiments.

\section{Minimum Inhibitory Concentration (MIC) Determination}

MICs were determined by the agar dilution method [11]. A series of two fold dilution of each sample, ranging from 300 to $0.85 \mathrm{mg} / \mathrm{ml}$ was prepared, at $50^{\circ} \mathrm{C}$, in TSA for bacteria and $\mathrm{SAB}$ for fungi and poured in a Petri plate. Plates were dried at $37^{\circ} \mathrm{C}$ for $30 \mathrm{~min}$ and then suspensions of bacterial and fungal strains were spotted onto the agar plates (10 $\mu 1)$. The final CFU inoculated onto the agar plates was approximately $10^{5}$ for each strain. The bacterial plates were incubated for $24 \mathrm{~h}$ at $37^{\circ} \mathrm{C}$ while the fungal plates were incubated at $25^{\circ} \mathrm{C}$ for $48 \mathrm{~h}$. Antibiotic control of ampicillin and amphotericin B were also prepared to obtain concentration ranges of $7 \times 10^{-3}-40 \mu \mathrm{g} / \mathrm{ml}$. MICs were defined as the lowest concentration of plant extract or antibiotic control inhibiting visible growth of each microbial strain on Petri plate. All determinations were performed in triplicate and two growth controls consisting of medium without plant extracts were included.

\subsection{Free Radical Scavenging Activity}

The free radical scavenging activity (FRS) of the extracts was determined by using 2,2-diphenyl-1-picrylhydrazyl radical (DPPH) method [12]. Briefly, both dried extracts and standard (ascorbic acid) were dissolved in $\mathrm{MeOH}$ at a concentration of $1 \mathrm{mg} / \mathrm{ml}$; stock solutions were then serially diluted in $\mathrm{MeOH}$ by two folds, giving test solutions at final concentration of $0.5,0.25,0.125,0.06 \mathrm{mg} / \mathrm{ml}$. Reaction mixture was prepared by adding $100 \mu \mathrm{l}$ of each extract solution (or standard solution) to $3.9 \mathrm{ml}$ of DPPH solution, freshly prepared dissolving DPPH in methanol/ $\mathrm{KH}_{2} \mathrm{PO}_{4}$ and $\mathrm{NaOH}$ buffer $(50 / 50 \mathrm{v} / \mathrm{v})$ at a concentration of $6 \times 10^{-5} \mathrm{M}$. After 20 min of incubation at room temperature, the absorbance was measured at $515 \mathrm{~nm}$ by a UV-Visible spectrophotometer (Lambda 25 UV/VIS spectrometer, Perkin Elmer instruments, Massachusetts, USA). 
FRS was expressed as a percent compared with the control, consisting of $3.9 \mathrm{ml}$ of DPPH solution and $100 \mu \mathrm{l}$ of methanol. The percent inhibition of the DPPH radical by the test solution was calculated using the following formula

$\mathrm{FRS} \%=\left[\left(\mathrm{Abs}_{\text {control }}-\mathrm{Abs}_{\text {sample }}\right) / \mathrm{Abs}_{\text {control }}\right] \times 100$

Each solution was prepared in triplicate. The analyses were carried out in triplicate and results are expressed as mean \pm SE.

\subsection{Anti-Inflammatory Activity}

Inhibition of TNF $\alpha$ from human peripheral blood mononuclear cells (hPBMC) in vitro was carried-out as previously described by us [13]. Briefly, hPBMC were separated by Ficoll-Hypaque centrifugation by buffy-coat from healthy donors and resuspended in RPMI 1640 containing 5\% of Foetal Bovine Serum (FCS) and maintained over night at $4{ }^{\circ} \mathrm{C}$. The next morning the cells were added to 96 -well flat bottom microtiter plate in the presence of serial doses of decoction (from 800 to $12 \mu \mathrm{g} / \mathrm{ml}$ ) or MASE $n$-Hex-Ac extract (from 400 to $6.2 \mu \mathrm{g} / \mathrm{ml}$ ) or medium (control cells) and incubated for $60 \mathrm{~min}$ at $37^{\circ} \mathrm{C}$. At the end of the incubation period, E.Coli lipopolysaccharides (LPS) was added at 10 $\mathrm{ng} / \mathrm{ml}$ and the cells were incubated for $24 \mathrm{~h}$ at $37^{\circ} \mathrm{C}$. The amount of $\mathrm{TNF} \alpha$ released in the supernatant was, then, measured by enzyme-linked immunosorbent assays (ELISA) (h- TNF $\alpha$ DuoSet, R\&D Systems, Minneapolis, MN, USA). The inhibition of TNF $\alpha$ production was expressed as inhibitory concentration $50 \%$ ( $\left.\mathrm{IC}_{50}\right)$ determined by using GraphPad 5.0 Software.

Cytotoxicity of the extracts was determined on parallel cell culture plate by using the Cell Titer 96 assay (Promega Italia, Milan, Italy) based on the use of the tetrazolium salt MTS and expressed as effective dose $50 \%\left(\mathrm{ED}_{50}\right)$.

Inhibition of $\mathrm{TNF} \alpha$ in vivo was carried-out as previously described [13]. Briefly, BALB/c mice (Charles River Italia, Calco, Italy) were treated by oral gavage with MASE extract suspended in $0.5 \%$ methyl-cellulose, in a final volume of $200 \mu \mathrm{l} / \mathrm{mouse}$. Vehicle treated mice received $200 \mu \mathrm{l}$ of water. After $60 \mathrm{~min}$. mice were injected i.p. with Salmonella $E$. LPS $(30 \mathrm{mg} / \mathrm{kg}$ ) and $90 \mathrm{~min}$ later $\mathrm{TNF} \alpha$ serum levels were measured by ELISA (m-TNF $\alpha$ DuoSet, R\&D Systems, Minneapolis, MN, USA).

\subsection{TLC Analysis}

Thin Layer Chromatography (TLC, Kieselgel 60 F254, $0.2 \mathrm{~mm}$, Merck, Germany) of extracts was performed using two different mobile phases [ethyl acetate-formic acid-water $(90: 5: 5 \mathrm{v} / \mathrm{v} / \mathrm{v})$ or chloroform-methanol-water (61:32:7 v/v/v)] combined with $\mathrm{FeCl}_{3}$ reagent (3\% in water) or ammonia vapour exposure for the identification of condensed tannins and flavonoids respectively [14].

\subsection{Statistical Analysis}

Data were analyzed by analysis of variance (ANOVA). Means were separated with the LSD method at confidence levels of $99 \%$ and $95 \%$.

\section{RESULTS AND DISCUSSION}

The first step of the present study was aimed at identifying the Badam Talkh kuhi's plant material that was classified by us as Amygdalus lycioides Spach [Family: Rosaceae, Genus: Amygdalus, Subgenus: Dodecandra, Species: lycioides; Syn.: Prunus lycioides C.K. Schneid], a very spiny, much branched, dense scrub about $1 \mathrm{~m}$ tall, with linear-lanceolate 1.5-3.0 $\mathrm{cm}$ long leaves which have sharp pointed apex and crenate-dentate margins $[15,16]$. Amygdalus lycioides is an endemic species extending into south Anatolia, growing on steep dry slopes made of limestone, sandstone or even granite, as well as in clayisch or gravelly habitats and covering a wide altitude range - from 200 to $2900 \mathrm{~m}$ [17].

Successively, different extracts of Amygdalus lycioides were prepared and their biological properties evaluated, applying the modern ethnobotanical approach which suggests firstly to perform preliminary bioassays on crude plant extracts and then to accomplish their bioactivity-directed fractionation aimed at obtaining the active compounds. To the best of our knowledge, no scientific evaluation of pharmacological activities of Amygdalus lycioides Spach extracts has been reported yet.

The decoction of Amygdalus lycioides was prepared essentially according to the procedure of the Iranian folk medicine. Maceration (ME), Ultrasound-Assisted Extraction (USAE) and Microwave-Assisted Solvent Extraction (MASE) were also experimented using two different extraction solvents, pure methanol $(\mathrm{MeOH})$ and $n$-hexane-acetone $(n-\mathrm{Hex}-\mathrm{Ac}, 50 \% \mathrm{v} / \mathrm{v})$. In order to remove the fat from the drug just before performing the extraction, a protocol involving a drug pre-treatment with petroleum ether was also applied [9, 18]. The yield of each dried extract was calculated in terms of percentage of the original drug weight and reported in Table $\mathbf{1}$.

In order to evaluate the medicinal potential of Amygdalus lycioides, the antimicrobial and anti-inflammatory properties of prepared extracts were investigated.

Preliminary antibacterial activity screening against $S$. aureus, E. coli and P. aeruginosa was performed on each extract, employing the agar disc diffusion method. Results are reported in Table $\mathbf{1}$.

Generally, tested extracts resulted effective against the Gram-positive $S$. aureus (IZD ranging from $15.4 \pm 0.8$ to 20 $\pm 0.7 \mathrm{~mm}$ ), with the only exception of methanolic extracts obtained applying USAE and ME methodologies. It can be outlined that the drug pre-treatment with petroleum ether gave rise to extracts showing enhanced antimicrobial activity with respect to those obtained without pre-treatment of the vegetable matrix. Moreover, a decrease of extraction yield was observed, proving the removal of biologically inactive components during the drug pre-treatment process. Regarding the activity against $E$. coli and $P$. aeruginosa, all tested extracts were found ineffective. As showed in Table 1, the highest antibacterial activity against $S$. aureus was observed for the extract obtained using $n$-Hex-Ac as extraction mixture and applying MASE methodology to pre-treated drug (IZD $20.0 \pm 0.7 \mathrm{~mm}$ ). Thus, the antimicrobial potential of this extract was deeply investigated by performing Growth inhibition test as well as MIC determination on different bacteria (C. sporogenes, E. hirae, S. mutans and S. pyogenes) and fungi (C. albicans and A. niger) strains. Interestingly, MASE $n$-Hex-Ac extract showed maximum activity against $C$. sporogenes (IZD of $30.3 \pm 2.1 \mathrm{~mm}$ and MIC of 1 
Table 1. Yield Extraction (\%) and IZD of Different Amygdalus lycioides Extracts

\begin{tabular}{|c|c|c|c|}
\hline Extraction Methodology & Extraction Solvent & \% Yield (w/w) & 11.2 \\
\hline \hline Decoction & Water & 1.7 & $16.9 \pm 0.5$ \\
\hline MASE & $n$-Hex-Ac . aureus & $20.0 \pm 0.7$ \\
\hline MASE & $n-\mathrm{Hex}-\mathrm{Ac}^{\mathrm{a}}$ & 1.5 & $16.2 \pm 0.5$ \\
\hline MASE & $\mathrm{MeOH}$ & 5.2 & $16.5 \pm 0.3$ \\
\hline MASE & $\mathrm{MeOH}{ }^{\mathrm{a}}$ & $15.4 \pm 0.8$ \\
\hline USAE & $n-\mathrm{Hex}-\mathrm{Ac}$ & 1.9 & $16.0 \pm 0.9$ \\
\hline USAE & $n-\mathrm{Hex}-\mathrm{Ac}{ }^{\mathrm{a}}$ & 1.2 & $\mathrm{NI}^{\mathrm{b}}$ \\
\hline USAE & $\mathrm{MeOH}$ & 3.8 & $\mathrm{NI}^{\mathrm{b}}$ \\
\hline USAE & $\mathrm{MeOH}{ }^{\mathrm{a}}$ & 3.6 & $16.7 \pm 0.3$ \\
\hline ME & $n-\mathrm{Hex}-\mathrm{Ac}$ & 2.7 & $17.0 \pm 0.3$ \\
\hline ME & $n-\mathrm{Hex}-\mathrm{Ac}{ }^{\mathrm{a}}$ & 2.4 & $\mathrm{NI}^{\mathrm{b}}$ \\
\hline ME & $\mathrm{MeOH}$ & 7.7 & $\mathrm{NI}^{\mathrm{b}}$ \\
\hline ME & $\mathrm{MeOH}{ }^{\mathrm{a}}$ & 6.5 & \\
\hline
\end{tabular}

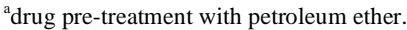

${ }^{b} \mathrm{NI}$ : no inhibition was observed.

IZD values are expressed as mean \pm SE of three determinations.

$\mathrm{mg} / \mathrm{ml}$ ), followed by $S$. mutans (IZD of $28.0 \pm 1.7 \mathrm{~mm}$ and MIC of $2.5 \mathrm{mg} / \mathrm{ml}$ ) and $S$. pyogenes (IZD of $26.5 \pm 1.7 \mathrm{~mm}$ and MIC $2.1 \mathrm{mg} / \mathrm{ml})$.

Moving from antimicrobial to anti-inflammatory properties evaluation, our approach consisted in performing a preliminary screening of all extracts by testing their free radical scavenging effect (FRS), given that reactive oxygen species (ROS) are involved in TNF $\alpha$-induced inflammation [19]. The most interesting extracts in terms of FRS effect were then selected to be further investigated concerning their $\mathrm{TNF} \alpha$ - blocker properties, by both in vitro and in vivo assays.

The FRS activity was evaluated by the DPPH assay, using ascorbic acid as standard. The antioxidant potential of extracts was initially evaluated at a stock concentration of 1 $\mathrm{mg} / \mathrm{ml}$. Successively, stock solutions were serially diluted into a range of $0.5-0.06 \mathrm{mg} / \mathrm{ml}$ and their corresponding FRS activity was determined. Basing on results obtained during the antimicrobial activity study, only the extracts prepared from pre-treated drug were considered. Generally, an interesting FRS activity was evidenced for all Amygdalus lycioides extracts (Table 2). Particularly, in the high doses range $(\geq 0.25 \mathrm{mg} / \mathrm{ml})$ all the extracts showed a significantly $(\mathrm{p}<$ $0.05)$ higher effect with respect to ascorbic acid. On the contrary, in the low doses range $(<0.25 \mathrm{mg} / \mathrm{ml})$ the strongest antioxidant effect was observed for the extract obtained applying MASE methodology and $n$-Hex-Ac extraction mixture. In fact, only MASE $n$-Hex-Ac extract showed a FRS profile similar to that of ascorbic acid (Table 2 ).

Table 2. FRS \% of Amygdalus lycioides Extracts and STD (Ascorbic Acid)

\begin{tabular}{|c|c|c|c|c|c|c|c|c|}
\hline \multirow{4}{*}{ Conc $^{\mathrm{a}}$} & \multicolumn{8}{|c|}{ FRS \% } \\
\hline & \multicolumn{7}{|c|}{ Amygdalus lycioides Extracts } & STD \\
\hline & \multicolumn{3}{|c|}{ МеОН } & \multicolumn{3}{|c|}{ Hex-Ac $(50 / 50$ v/v $)$} & \multirow{2}{*}{$\begin{array}{c}\text { Water } \\
\text { Decoction }\end{array}$} & \multirow{2}{*}{ Ascorbic Acid } \\
\hline & MASE & USAE & ME & MASE & USAE & ME & & \\
\hline 0.06 & $26.59 \pm 0.4$ & $25.77 \pm 1.1$ & $30.45 \pm 1.9$ & $49.01 \pm 1.1$ & $30.03 \pm 0.7$ & $27.54 \pm 2.9$ & $17.13 \pm 1.5$ & $59.50 \pm 1.2$ \\
\hline 0.125 & $35.66 \pm 0.6$ & $20.20 \pm 2.2$ & $53.42 \pm 0.7$ & $54.89 \pm 0.9$ & $45.45 \pm 0.6$ & $35.04 \pm 1.4$ & $28.77 \pm 1.1$ & $56.61 \pm 1.1$ \\
\hline 0.25 & $59.16 \pm 0.6$ & $52.88 \pm 2.1$ & $64.02 \pm 1.3$ & $61.58 \pm 1.2$ & $59.88 \pm 0.9$ & $55.03 \pm 0.6$ & $57.48 \pm 1.9$ & $56.20 \pm 3.0$ \\
\hline 0.5 & $61.50 \pm 1.4$ & $62.86 \pm 0.3$ & $64.55 \pm 0.7$ & $63.16 \pm 0.8$ & $64.28 \pm 1.5$ & $57.79 \pm 1.7$ & $60.82 \pm 0.7$ & $54.27 \pm 2.5$ \\
\hline 1.0 & $63.28 \pm 0.3$ & $64.67 \pm 1.9$ & $64.58 \pm 0.4$ & $65.13 \pm 0.9$ & $64.99 \pm 2.4$ & $57.92 \pm 1.4$ & $70.23 \pm 0.9$ & $54.83 \pm 1.8$ \\
\hline
\end{tabular}

${ }^{\mathrm{a}} \mathrm{mg} / \mathrm{ml}$.

FRS $\%$ values are expressed as mean \pm SE of three determinations. 
Table 3. TNF $\alpha$ Effect and Cytotoxicity of Amygdalus lycioides Extracts

\begin{tabular}{|c|c|c|}
\hline Extraction Methodology & TNF $\alpha$ Inhibition $\left(\mathbf{I C}_{\mathbf{5 0}}, \boldsymbol{\mu g} / \mathbf{m l}\right)$ & ${\text { Cytotoxicity }\left(\mathbf{E D}_{\mathbf{5 0}}, \boldsymbol{\mu g} / \mathbf{m l}\right)}$ \\
\hline \hline MASE $(n$-Hex-Ac) & 20.0 & $\approx 100$ \\
Donor A & $<6.2$ & $>800$ \\
Donor B & & $>800$ \\
\hline Decoction & 387.0 & $>>800$ \\
Donor A & 119.9 & \\
Donor B & & \\
\hline
\end{tabular}

Basing on these results MASE extract obtained from plant material pre-treated with petroleum ether and using $n$ Hex-Ac as extraction mixture (by now on called the MASE extract) was selected for the TNF $\alpha$-activity evaluation. The anti-inflammatory efficacy of decoction was also assayed according to the traditional use of Amygdalus lycioides.

TNF $\alpha$ production by hPBMC was induced in vitro by a treatment with E. Coli endotoxin (LPS) for $24 \mathrm{~h}$ in the presence of serial doses of both extracts. The TNF $\alpha$ levels in the cell supernatant was measured by ELISA and the inhibitory activity expressed as $\mathrm{IC}_{50}$; hPBMC were obtained from 2 different donors and the results are reported in Table $\mathbf{3}$. To confirm that the inhibitory effect was specific and to exclude that it was due to cytotoxicity, the vitality of the cells was determined and expressed as $\mathrm{ED}_{50}$.

MASE extract dose-dependently inhibits TNF $\alpha$ with an $\mathrm{IC}_{50}$ of $20 \mu \mathrm{g} / \mathrm{ml}$ on donor $\mathrm{A}$, whereas on the second donor appear to be more potent with an $\mathrm{IC}_{50}$ value lower than 6.2 $\mu \mathrm{g} / \mathrm{ml}$ (the lowest concentration tested). The inhibition was clearly due to a specific cellular effect on $\mathrm{TNF} \alpha$ synthesis since MASE extract did not cause any toxic effect at the active concentrations. In fact, on donor A the cytotoxicity was negligible at the higher dose used $\left(\mathrm{ED}_{50}\right.$ higher than 800 $\mu \mathrm{g} / \mathrm{ml})$, whereas on donor B cytotoxicity $\left(\mathrm{ED}_{50}\right.$ about 100 $\mu \mathrm{g} / \mathrm{ml}$ ) was evident at concentrations significantly higher than the effective dose on TNF $\alpha\left(\mathrm{IC}_{50}<6.2 \mu \mathrm{g} / \mathrm{ml}\right)$. Decoction resulted similarly active as TNF $\alpha$ inhibitor but its potency was lower than that of MASE extract, in fact the $\mathrm{IC}_{50}$ values were about $390 \mu \mathrm{g} / \mathrm{ml}$ and $120 \mu \mathrm{g} / \mathrm{ml}$ on donor A and $\mathrm{B}$, respectively. As for MASE extract, the anti- TNF $\alpha$ activity of the decoction is specific since on the cells of both donors no signs of cytotoxicity were detected.

Due to the in vitro efficacy of the MASE extract, its in vivo activity (using a model of systemic inflammation, i.e. the LPS-induced TNF $\alpha$ production in the mouse) was also evaluated. In detail, MASE extract was administered orally at the dose of 50 and $100 \mathrm{mg} / \mathrm{kg}, 60 \mathrm{~min}$ before LPS administration. The reduction of circulating level of $\mathrm{TNF} \alpha$ was measured $90 \mathrm{~min}$ later, corresponding to the time point of the circulating peak concentration of the cytokine. Results reported in Fig. (1) indicate that the lower dose $(50 \mathrm{mg} / \mathrm{kg})$ did not inhibit significantly the $\mathrm{TNF} \alpha$ release, whereas the higher dose $(100 \mathrm{mg} / \mathrm{kg})$ is effective in reducing TNF $\alpha$ of about $60 \%(3.8 \mathrm{ng} / \mathrm{ml}$ vs. $9.8 \mathrm{ng} / \mathrm{ml}$ in the LPS control group). It should be noted that the treated animals did not show any signs of toxicity during the overall experimental period.
The overall anti-inflammatory results indicate that both Amygdalus lycioides extracts have anti- TNF $\alpha$ properties in vitro and the MASE extract is also orally effective in vivo.

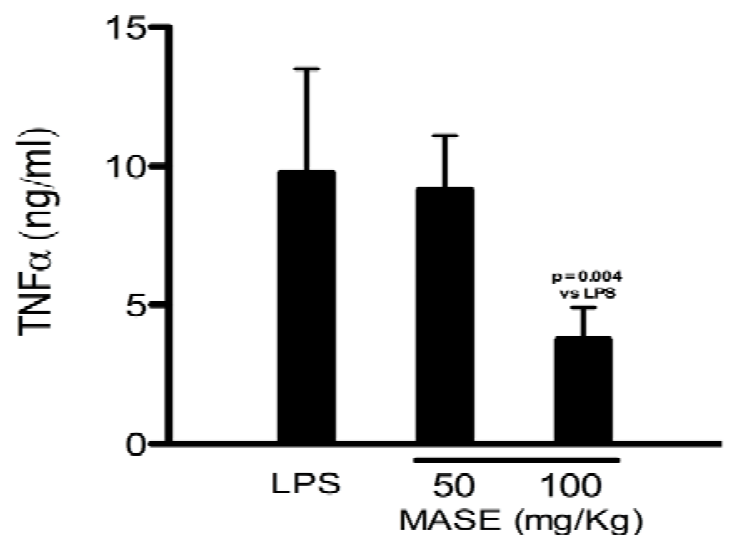

Fig. (1). Effect of MASE extract on LPS-induced TNF $\alpha$ production in mouse.

Following biological activity results, MASE extract was analyzed by TLC for a qualitative screening of its phytochemical composition. Interestingly, visual inspection of TLC plates under a UV lamp at $254 \mathrm{~nm}$ as well as coloration of the spots with specific reagents revealed the presence of condensed tannins and flavonoids.

\section{CONCLUSIONS}

In the present paper the ethnomedical use of Amygdalus lycioides Spach was assessed. Particularly, of high interest is the anti-inflammatory activity via $\mathrm{TNF} \alpha$-blocker mechanism of $n$-Hex-Ac MASE extract, which resulted effective both in vitro and in vivo at non toxic doses.

Results herein reported can be considered a useful starting point for the discovery of new anti-inflammatory compounds effective against chronic inflammatory diseases, such as rheumatoid arthritis and inflammatory bowel diseases.

Present efforts are directed to perform bioassay-guided purification of $n$-Hex-Ac MASE extract in order to isolate and to identify the active constituents, which belong to tannin and flavonoid chemical classes as evidenced by TLC analysis.

\section{REFERENCES}

[1] Yeh, S.L.; Wang, H.M.; Chen, P.Y.; Wu, T.C. Interactions of $\beta$ carotene and flavonoids on the secretion of pro-inflammatory mediators in an in vivo system. Chem. Biol. Interact., 2009, 179, 386393. 
[2] Ratheesh, M.; Shyni, G.L.; Sindhu, G.; Helen, A. Protective effect of isolated polyphenolic and alkaloid fractions of Ruta graveolens L. on acute and chronic models of inflammation. Inflammation, 2010, 33(1), 18-24.

[3] Auron, P.E.; Webb, A.C.; Rosenwasser, L.J.; Mucci, S.F.; Rich, A.; Wolff, S.M.; Dinarello, C.A. Nudeotide sequence of human monocyte interleukin I precursor cDNA. Proc. Natl. Acad. Sci. USA, 1984, 81, 7907-7911.

[4] Dinarello, C.A. The interleukin-1 family: 10 years of discovery. FASEB J., 1994, 8, 1314-1325.

[5] Dinarello, C.A. Proinflammatory cytokines. Chest, 2000, 118, 503508 .

[6] Tracey, D.; Klareskog, L.; Sasso, E.H.; Salfeld, J.G.; Tak, P.P. Tumor necrosis factor antagonist mechanisms of action: a comprehensive review. Pharmacol. Ther., 2008, 117, 244-79.

[7] Ornetti, P.; Chevillote, H.; Zerrak, A.; Maillerfert, J.F. Anti-tumor necrosis factor-alpha therapy for rheumatoid and other inflammatory arthropathies: update on safety in older patients. Drugs Aging, 2006, 23(11), 855-860.

[8] Parsa, A. Medicinal plants and drugs of plant origin in Iran IV. Plant Foods Hum. Nutr., 1960, 7, 65-136.

[9] Miller, R.B.; McConville, M.J.; Woodrow, I.E. Cyanogenic glycosides from the rare Australian endemic rainforest tree Clerodendrum grayi (Lamiaceae). Phytochemistry, 2005, 67, 43-51.

[10] Bauer, S.W.; Kirby, W.M.; Sherris, J.C.; Thurck, M. Antibiotic susceptibility testing by standardized single disc method. Am. J. Pathol., 1966, 45, 493-496.

[11] National Committee for Clinical Laboratory Standard. Methods for Antimicrobial Susceptibility Testing for Bacteria that Grow Aerobically. Approved Standard. NCCLS Publication no. M7-A4 (4th ed.): Wayne: PA 1998.
[12] Papetti, A.; Daglia, M.; Gazzani, G. Anti- and pro-oxidant water soluble activity of Cichorium genus vegetables and effect of thermal treatment. J. Agric. Food Chem., 2002, 50, 4696-4704.

[13] Leoni, F.; Fossati, G.; Lewis, E.; Lee, J.K.; Porro, G.; Pagani, P.; Modena, D.; Moras, M.L.; Pozzi, P.; Reznikov, L.L.; Siegmund, B.; Fantuzzi, G.; Dinarello, C.A.; Mascagni, P. The histone deacetylase inhibitor ITF2357 reduces production of pro-inflammatory cytokines in vitro and systemic inflammation in vivo. Mol. Med., 2005, 11, 1-15.

[14] Orhan, N.; Aslan, M.; Orhan, D.D.; Ergun, F.; Yesilada, E. In-vivo assessment of antidiabetic and antioxidant activities of grapevine leaves (Vitis vinifera) in diabetic rats. J. Ethnopharmacol., 2006, 108, 280-286.

[15] Rechinger, K.H. Flora Iranica a Monumental Work on Plants of Persia. Akademische Druck U Verlagsanstalt: Graz, 1963, Vol. 66.

[16] Davis, P.H. Flora of Turkey and the East Aegean Island. Edinburgh University Press: Edinburgh, 1985, Vol. IV.

[17] Browicz, K.; Zohary, D. The genus Amygdalus L. (Rosaceae) Species relationships, distribution and evolution under domestication. Genet. Resour. Crop. Evol., 1996, 43, 229-247.

[18] Okolo, C.O.; Johnson, P.B.; Abdurahman, E.M.; Aguye, I.A.; Hussaini, I.M. Analgesic effect of Irvingia gabonensis stem bark extract. J. Ethnopharmacol., 1995, 45, 125-129.

[19] Young, C.N.; Koepke, J.I.; Terlecky, L.J.; Borkin, M.S.; Boyd, S.L.; Terlecky, S.R. Reactive oxygen species in tumor necrosis factor- $\alpha$-activated primary human keratinocytes: implications for psoriasis and inflammatory skin disease. J. Invest. Dermatol., 2008, $128,2606-2614$.

(C) Gaggeri et al.; Licensee Bentham Open.

This is an open access article licensed under the terms of the Creative Commons Attribution Non-Commercial License (http://creativecommons.org/licenses/by-nc/3.0/) which permits unrestricted, non-commercial use, distribution and reproduction in any medium, provided the work is properly cited. 